\title{
Video Article \\ Method for the Isolation and Identification of mRNAs, microRNAs and Protein Components of Ribonucleoprotein Complexes from Cell Extracts using RIP. Chip
}

\author{
Garrett M. Dahm ${ }^{1,2}$, Matthew M. Gubin ${ }^{1,2}$, Joseph D. Magee ${ }^{2}$, Patsharaporn Techasintana ${ }^{1,2}$, Robert Calaluce ${ }^{2}$, Ulus Atasoy $^{1,2,3}$ \\ ${ }^{1}$ Molecular Microbiology and Immunology, University of Missouri \\ ${ }^{2}$ Department of Surgery, University of Missouri \\ ${ }^{3}$ Child Health, University of Missouri
}

Correspondence to: Ulus Atasoy at atasoyu@missouri.edu

URL: https://www.jove.com/video/3851

DOI: doi:10.3791/3851

Keywords: Genetics, Issue 67, Molecular Biology, Cellular Biology, RNA, mRNA, Ribonucleoprotein, immunoprecipitation, microarray, PCR, RIPChip

Date Published: 9/29/2012

Citation: Dahm, G.M., Gubin, M.M., Magee, J.D., Techasintana, P., Calaluce, R., Atasoy, U. Method for the Isolation and Identification of mRNAs, microRNAs and Protein Components of Ribonucleoprotein Complexes from Cell Extracts using RIP-Chip. J. Vis. Exp. (67), e3851, doi:10.3791/3851 (2012).

\section{Abstract}

As a result of the development of high-throughput sequencing and efficient microarray analysis, global gene expression analysis has become an easy and readily available form of data collection. In many research and disease models however, steady state levels of target gene mRNA does not always directly correlate with steady state protein levels. Post-transcriptional gene regulation is a likely explanation of the divergence between the two. Driven by the binding of RNA Binding Proteins (RBP), post-transcriptional regulation affects mRNA localization, stability and translation by forming a Ribonucleoprotein (RNP) complex with target mRNAs. Identifying these unknown de novo mRNA targets from cellular extracts in the RNP complex is pivotal to understanding mechanisms and functions of the RBP and their resulting effect on protein output. This protocol outlines a method termed RNP immunoprecipitation-microarray (RIP-Chip), which allows for the identification of specific mRNAs associated in the ribonucleoprotein complex, under changing experimental conditions, along with options to further optimize an experiment for the individual researcher. With this important experimental tool, researchers can explore the intricate mechanisms associated with posttranscriptional gene regulation as well as other ribonucleoprotein interactions.

\section{Video Link}

The video component of this article can be found at https://www.jove.com/video/3851/

\section{Protocol}

\section{Experiment preparation}

Before starting experiment, it is critical to have all reagents, containers and utensils RNase free. Treat glassware with RNase inhibitor (RNaseZAP, Ambion) followed by rinsing with DEPC-treated water. Ensure that all reagents are confirmed as RNase free.

\section{Prepare mRNP Lysate}

1. Grow and harvest exponentially growing tissue cells to produce between $2-5 \mathrm{mg}$ of total protein for each RIP.

a. Two P150 culture dishes are usually sufficient.

b. For each RBP being investigated, total cellular number and protein amounts must be optimized to maximize appropriate target mRNA and RBP interactions.

c. RIP for qRT-PCR analysis may require less cellular lysate (approximately $400 \mu \mathrm{g}$ total protein) due to its amplification and detection method especially for high abundance RBPs such as HuR, AUF1, TIAR.

2. Pellet cells via centrifugation at $200 \times \mathrm{g}$ for $8-10 \mathrm{~min}$ at $4{ }^{\circ} \mathrm{C}$, then wash three times with ice cold PBS.

3. After final wash, gently flick the bottom of the tube and resuspend cell pellet in equal volumes of prepared polysome lysis buffer (PLB) with RNase and protease inhibitors.

a. It's recommended to measure out the exact volume of cell pellet.

4. Gently pipet mixture (do not vortex) to break apart clumps of cells and incubate lysate on ice for $5 \mathrm{~min}$.

5. Centrifuge at $13,000 \times \mathrm{g}$ for $20 \mathrm{~min}$ at $4{ }^{\circ} \mathrm{C}$ to clear the lysate of debris.

6. Immediately transfer cleared supernatant to pre-chilled microfuge tube.

7. Keep on ice and store at $-80^{\circ} \mathrm{C}$. 
a. Immediate freezing completes the proper lysis of the cells and prevents unwanted binding. Proceed with RIP immediately following sample thaw and keep samples on ice to avoid RNA degradation.

b. This lysate can be stored for up to six months at $-80^{\circ} \mathrm{C}$. Avoid repeated freeze thaw cycles as this can lead to protein and/or mRNA degradation.

8. Quantitate protein concentration in lysate using standard Bradford Protein assay.

\section{Coat Protein A Sepharose Beads with Antibody and Wash}

1. Pre-swell protein A Sepharose (PAS) beads overnight in NT2 buffer (3-4 volumes) with $5 \%$ BSA. Store at $4{ }^{\circ} \mathrm{C}$.

a. Long term storage of up to several months at $4{ }^{\circ} \mathrm{C}$ is possible when supplemented with $0.1 \%$ sodium azide.

b. Protein Sepharose beads should be chosen based on isotype of target RBP antibody. Proteins $A, G$ and $A / G$ all have specific isotype targets and vary in target affinity. Protein A sepharose beads were used based on isotype specificity and affinity for HuR protein antibody.

2. Before use, remove excess NT2 buffer, so that final beads to buffer ratio is $1: 1$

3. Using $1.5 \mathrm{ml}$ RNAse-free microcentrifuge tubes, remove $100 \mu \mathrm{l}$ of PAS slurry and add $30 \mu \mathrm{g}$ of antibody for each individual IP reaction (i.e., specific RBP and isotype control).

4. Add $100-200 \mu$ of NT2 buffer to antibody bead mix.

a. Mixture may be stored for several weeks at $4{ }^{\circ} \mathrm{C}$ when supplemented with $0.1 \%$ sodium azide.

b. An isotype-matched antibody or whole normal sera from same species should be used in parallel as an antibody control against background RNA.

5. Add appropriate antibody to bead mix and incubate overnight, tumbling end over end at $4{ }^{\circ} \mathrm{C}$.

a. Optimize antibody titer for specific protein being investigated (1, 5, 10 or $30 \mu \mathrm{g}$ of antibody is usually sufficient).

6. Prepare antibody-coated beads immediately before use by washing with $1 \mathrm{ml}$ of ice-cold NT2 buffer 5 times.

a. Wash bead mix by centrifugation at $13,000 \times \mathrm{g}$ for $1-2 \mathrm{~min}$ at $4{ }^{\circ} \mathrm{C}$.

b. Carefully remove the maximum amount of supernantant with hand pipettor or aspirator but be careful to avoid disrupting pellet.

c. Washing helps remove unbound antibody as well as RNase contaminants from antibody mixture.

7. Once the final wash has been completed, resuspend the beads in $700 \mu$ of ice-cold NT2 buffer followed by treatment with various RNase inhibitors to protect the target mRNAs, including $10 \mu \mathrm{l}$ of RNase Out at $40 \mathrm{U} / \mu \mathrm{l}, 10 \mu \mathrm{l}$ of $100 \mathrm{mM}$ DTT and $15 \mu \mathrm{l}$ EDTA (15 mM). Bring volume to $1,000 \mu$ with NT2 buffer.

a. Vanadyl ribonucleoside complexes are not used due to inhibitory effect of EDTA.

\section{Immunoprecipitation and RNA Precipitation}

1. Optional Preclear Step:

a. To reduce background, beads and control antibody may be used to pre-clear lysate. This may reduce signal in the output.

b. This step may be necessary to reduce background when doing IP followed by microarray. It is generally not necessary for IP followed by qRT-PCR.

c. Preclear with $15 \mu \mathrm{g}$ of isotype control for $30 \mathrm{~min} / 4{ }^{\circ} \mathrm{C}$ tumbling end over end.

d. Add $50 \mu$ of preswollen PAS beads non-coated with antibody from step 2.1.

e. Incubate $30 \mathrm{~min} / 4^{\circ} \mathrm{C}$ with rotation end over end

f. Centrifuge at $10,000 \times \mathrm{g}$ at $4^{\circ} \mathrm{C}$. Save supernatant for IP.

2. Add $100 \mu \mathrm{l}$ of isolated cleared lysate (approximately $2-5 \mathrm{mg}$ ) to prepared antibody mix.

a. Diluting lysate will help to reduce background and nonspecific binding.

b. Amount of lysate input may vary depending on detection method and abundance of RBP or efficiency of RBP antibody as noted in step 1.1.c.

3. (Optional) Immediately mix tube by gently flicking several times followed by brief centrifugation at $10,000 \times \mathrm{g}$ at $4{ }^{\circ} \mathrm{C}$ to pellet beads and immediately remove $100 \mu \mathrm{l}$ of supernatant as a total input mRNA representation for qPCR analysis using standard RNA isolation techniques.

a. This step is to confirm that input lysate RNA is optimal for IP and should only be performed as a check step or as a troubleshooting step following RIP with poor RNA results.

4. Wrap tube in parafilm to ensure tight sealing and incubate at $4{ }^{\circ} \mathrm{C}$ for 2 to $4 \mathrm{hr}$, tumbling end over end

a. Timing on incubation should be optimized based on target abundance and should be minimized to avoid complex rearrangement or degradation. For some RBPs shorter incubations may be more optimal.

5. Pellet beads at $5,000 \times \mathrm{g}$ for $5 \mathrm{~min}$ at $4{ }^{\circ} \mathrm{C}$ and save supernatant for potential analysis by Western blot. Store aliquots at $-80{ }^{\circ} \mathrm{C}$.

a. Aliquots of supernatant with high amounts of residual target protein may indicate a failure of the protein to be precipitated by sepharose beads.

6. As described previously, wash beads 5 times with $1 \mathrm{ml}$ of ice-cold NT2 buffer and centrifugation $\left(5,000 \times \mathrm{g}\right.$ for $5 \mathrm{~min}$ at $\left.4{ }^{\circ} \mathrm{C}\right)$ then remove supernatant with hand pipettor or an aspirator.

a. More stringent wash methods may be used in order to reduce background by supplementing NT2 buffer with sodium deoxycholate, urea or SDS. 
b. Keep samples on ice as much as possible and work quickly to minimize degradation of target mRNA.

7. Optional: Save a small aliquot (10\%) of bead mix or run an additional sample in parallel for checking the IP efficiency of target protein using Western blot analysis.

\section{DNase and Proteinase K Treatments}

1. After washing, resuspend beads with $100 \mu \mathrm{l}$ of NT2 buffer supplemented with $5 \mu \mathrm{l}$ of RNase-free DNase $1(2 \mathrm{U} / \mu \mathrm{l})$.

2. Keep at $37^{\circ} \mathrm{C}$ for $5-10 \mathrm{~min}$. Add $1 \mathrm{ml}$ of NT2 buffer and centrifuge at 5,000 $\mathrm{gg}$ for $1 \mathrm{~min}$ at room temperature.

a. A small $(\sim 10 \%)$ aliquot of beads may be used to check the IP efficiency by SDS-PAGE analysis.

3. Resuspend PAS pellet in $100 \mu \mathrm{l} \mathrm{NT2} \mathrm{buffer,} 5 \mu \mathrm{l}$ Proteinase $\mathrm{K}(10 \mathrm{mg} / \mathrm{ml})$, and $1 \mu \mathrm{l} 10 \%$ SDS.

4. Incubate the resuspended bead mixture for $30 \mathrm{~min}$ at $55^{\circ} \mathrm{C}$ in a water bath, gently flicking at every $10 \mathrm{~min}$.

a. Proteinase $\mathrm{K}$ will aid in the release of the RNP components.

5. Pellet beads at $5,000 \times \mathrm{g}$ for $5 \mathrm{~min}$ at room temperature (RT) and collect the supernatant $(\sim 100 \mu \mathrm{l})$.

6. Add $200 \mu \mathrm{l}$ NT2 buffer to beads, centrifuge $5,000 \times \mathrm{g}$ for 2 min at RT, collect supernatant ( $200 \mu \mathrm{l})$, and discard beads.

7. Combine supernatants $(100 \mu \mathrm{l}$ and $200 \mu \mathrm{l})$ and add $300 \mu \mathrm{l}$ lower layer of acid phenol- $\mathrm{CHCl}_{3}$.

8. Vortex, $1 \mathrm{~min} \mathrm{RT}$ (or $37^{\circ} \mathrm{C}$ in shaker) and centrifuge at $16,000 \mathrm{xg}$ at RT for $1 \mathrm{~min}$.

9. Collect $250 \mu \mathrm{l}$ of upper layer (DO NOT disrupt interface), add $25 \mu \mathrm{l}$ sodium acetate at pH 5.2, $625 \mu \mathrm{l} 100 \%$ ETOH and $5 \mu \mathrm{l}$ glycoblue, and mix well.

10. Store overnight at $-20^{\circ} \mathrm{C}$.

a. To ensure proper recovery of RNA, the addition of glycoblue will increase the visibility of the RNA pellet by acting as a carrier molecule.

11. The following day, mix tubes by inversion 3-5 times, spin at $12,000 \times \mathrm{g}$ at $4{ }^{\circ} \mathrm{C}$ for $30 \mathrm{~min}$ and discard the supernatant.

12. Add $1 \mathrm{ml}$ of $70 \% \mathrm{ETOH}$ to the blue pellet and mix by inversion or vortexing.

13. Centrifuge $12,000 \mathrm{xg}$ at $4{ }^{\circ} \mathrm{C}$ for $2 \mathrm{~min}$.

14. Discard supernatant and centrifuge $12,000 \times \mathrm{g}$ for $1 \mathrm{~min}$ at $4{ }^{\circ} \mathrm{C}$.

15. Remove any residual $70 \%$ ETOH with a pipette and air dry pellet at RT for $5 \mathrm{~min}$.

16. Resuspend in 20-40 $\mu$ l of RNase/DNase-free water or another appropriate volume as needed.

a. Sample is now ready for further downstream applications such as qRT-PCR or microarray.

b. Nanodrop spectrophotometry may be used in assessing sample concentration; however, with precious samples, it may be beneficial to avoid nanodropping samples as it can be wasteful and relatively inaccurate. We suggest normalizing samples to housekeeping gene transcripts to assess purity and IP efficiency for precious or low yield samples.

\section{Representative Results}

If the procedure is optimized and performed correctly, the immunoprecipitation should yield significant enrichment of mRNA targets. Typically, depending on the RBP and its mRNA target(s), we see enrichment of approximately 10- to 50-fold when assessed by qRT-PCR. Many targets of RBPs can be discovered en masse using microarray analysis. However, this method is more sensitive to degradation as compared with qRTPCR. Depending on the RBP, the number of targets and the efficiency of the reaction, microarray can reveal hundreds of novel targets, or it may only uncover a few, if any. For example, one of the better characterized RNA binding proteins HuR, post-transcriptionally regulates the expression and translation of many important physiological genes ${ }^{1,2}$. Isolation of the HuR-ribonucleo-complex via RIP-Chip in breast cancer cell lines, for instance, revealed enrichment of several important known HuR targets, including $\beta$-actin using qRT-PCR as shown in Figure 1. In both cancer cell lines $\beta$-actin is enriched 12- to 15-fold. Typically, when performed properly we see a significant enrichment of $\beta$-actin in a variety of cell lines. However, if the RIP does not reveal any significant enrichment for $\beta$-actin this indicates a problem with the RIP and the procedure may need to be repeated. Furthermore, microarray analysis of immunoprecipitated samples from these cell lines revealed distinct expression subsets of HuR targets in different estrogen receptor (ER) positive MCF-7 cancer cells versus ER negative MB-231 breast cancer cell lines as demonstrated in Figure $2^{1}$. These targets fall into several categories: known and unknown HuR targets that were either associated or not associated with cancer. For example, CALM2 and CD9 are both cancer genes which were not previously identified as HuR targets. Using the microarray and confirming with qRT-PCR, CALM2 and CD9 were found to be 5- to 180-fold enriched in the HuR pellet indicating a prominent interaction between the HuR protein and these target genes. 
A

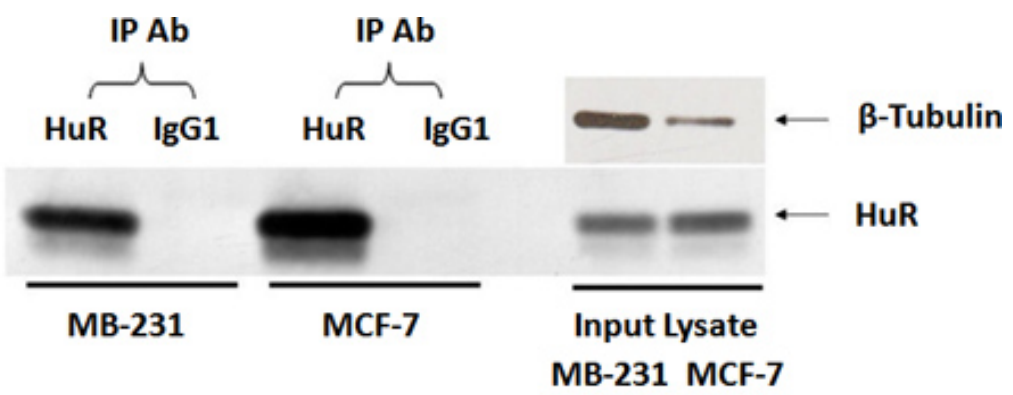

B

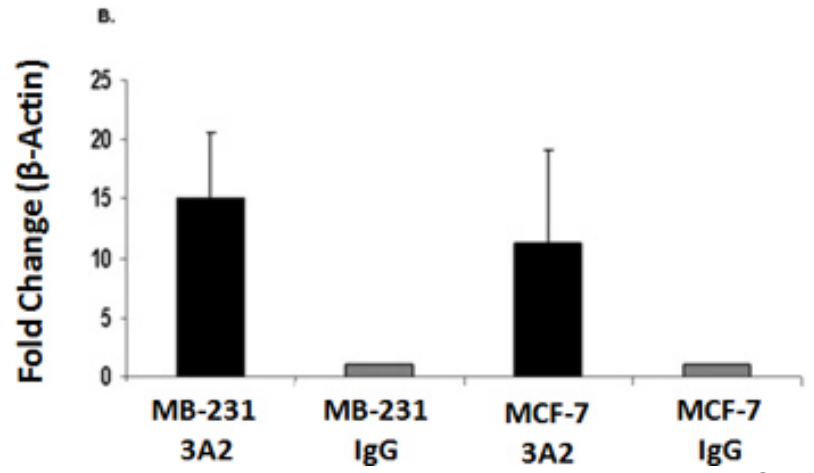

Figure 1. Immunoprecipitation and RIP in MB-231 (ER-) and MCF-7 (ER+) breast cancer cells. Immunoprecipitations were performed from MB-231 or MCF-7 cell lysates using anti-HuR monoclonal antibody (3A2) and IgG1 isotype control. A. IP Western of HuR revealed expected size band as detected by $3 A 2$. Panel on right reveals amounts of HuR in input lysates used from both cell lines, with $\beta$-tubulin as a loading control. B. Verification by quantitative RT-PCR showed fifteen- and eleven-fold enrichments of $\beta$-actin, a known HuR target, in the 3A2 IPs from MB-231 and MCF-7, respectively. All $\triangle \triangle$ CT values were normalized to GAPDH. Experiments were done in duplicate $(n=2)$.

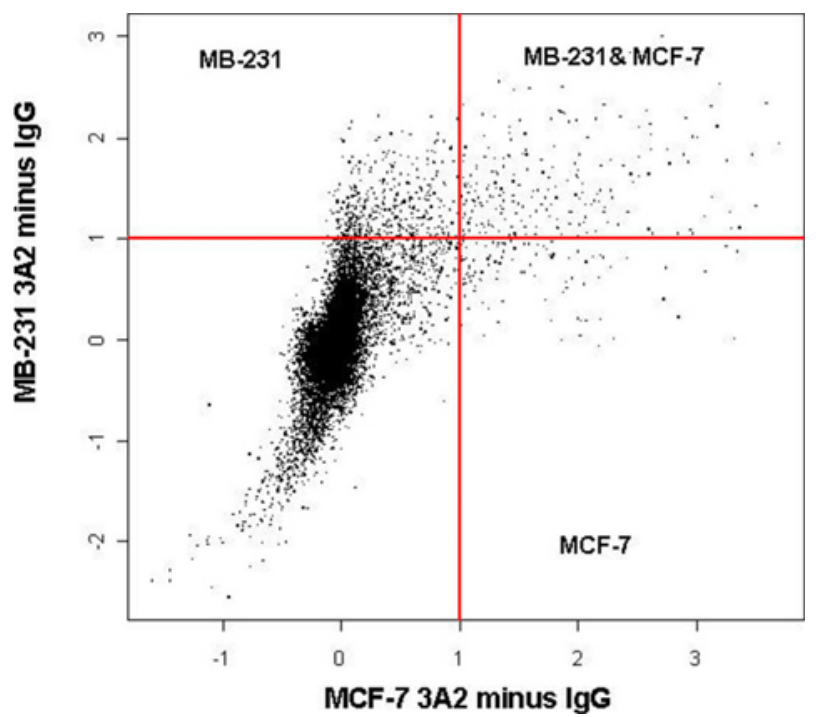

Figure 2. HuR RIP-CHIP identifies distinct genetic profiles in ER+ and ER- breast cancer cells. HuR immunoprecipitations were performed from MB-231 or MCF-7 cell lysates using HuR antibody and IgG1 isotype control hybridized to lllumina Sentrix arrays (47,000 genes). Control signals were subtracted. Results represent cumulative data from 12 different arrays. Experiments were done in triplicate $(n=3)$ for each cell line with matching controls. Scales are log2.

\section{Discussion}

Due to the nature of this experiment, optimization and experience will be the only guaranteed ways to successfully acquire the intended results. In many steps of this procedure, temperature and efficient handling of the reagents and products are critically important. Proper planning and execution of technique will help insure that the experiment was performed in an appropriate timeframe at the optimal temperatures recommended. A major issue with RNA isolation experiments is the sensitivity of RNAs to degradation by RNases. All reagents need to be RNase free and stored or used in RNase-free containers. This is a critical step in ensuring the integrity of your mRNA sample. Even when the 
experiment is performed properly, however, the desired outcome may not be achieved due to the nature of the interaction between the RBP and its target mRNAs.

One potential problem is having low or even no signal from the RNA isolated by RIP-Chip. Although there may be signal from total RNA, this may be the result of inadequate binding protein being pulled down by the beads. The first troubleshooting step is to confirm that the cellular lysate being used has adequate expression of the specific RBP. Upon confirmation, protein may be isolated after the final NT2 wash and resuspended in Laemmli buffer or another appropriate denaturing buffer and heated at $95^{\circ} \mathrm{C}$ for $5 \mathrm{~min}$. Western blot analysis may be used on these samples in coordination with input lysate as well as negative controls to ensure sufficient pull down of associated protein.

Furthermore, because lysing the cell is required to access these components, the potential for abnormal and unwanted interactions between normally separated proteins and mRNA may be introduced. These interactions could potentially bind and "soak up" your target mRNAs or binding proteins through nonspecific interactions. Additionally, proteins in these varying conditions can fold in multiple variations and their binding motifs may become inaccessible to their target mRNAs, preventing their interactions. Both of these strengthen the importance of working efficiently as well as utilizing the optimal temperatures listed to limit these unwanted interactions. Additionally, optimization of washing conditions for each specific target protein will be critical to maximize the purity of the interaction. More stringent washing conditions may be needed. For example, the wash buffer may be supplemented with SDS or an appropriate amount of urea to reduce nonspecific interactions and background in your signal output. This will be completely dependent on the experimenter's target RBP as well as the target mRNA in their unique physiological conditions. Some conditions will not be suitable for certain mRNA analysis tools, which should be noted in preparation of samples.

Finally, though RIP is successful in the enrichment of RNA-RBP interactions, a well known issue with RIP (CHIP) method is the inability to identify the specific binding domains of the RBP on the transient mRNA targets. Several cross-linking techniques can be used followed by RIP to isolate unique sequence targets; however, the use of short-wave UV tends to lead to nucleic acid damage. A new method known as PARCLIP, or photoactivatable ribonucleoside crosslinking and immuoprecipitation, employs long-wave UV to incorporate thiouridine into nascent RNA allowing the identification of unique binding sites from both stable and transient RNA interactions.

Overall, RIP-Chip has been established as an excellent tool used to isolate and study the interactions between RNA binding proteins and their mRNA targets by our group as well as many other research groups. Though sensitive in nature and practice, proper execution of this procedure will yield the isolation of these RNP complexes, which until recently, have been inaccessible for discovery and analysis.

\section{Disclosures}

The authors declare that they have no competing interests.

\section{Acknowledgements}

Department of Defense (Idea Award W81XWH-07-0406) - To Ulus Atasoy

NIH RO1 A1080870 - To Ulus Atasoy

NIH R21 A1079341 - To Ulus Atasoy

University of Missouri Institutional Funds - To Ulus Atasoy

\section{References}

1. Calaluce, R., Gubin, M.M., Davis, J.W., Magee, J.D., Chen, J., Kuwano, Y., Gorospe, M., \& Atasoy, U. The RNA binding protein HuR differentially regulates unique subsets of mRNAs in estrogen receptor negative and estrogen receptor positive breast cancer. BMC Cancer. 10, 126-140 (2010).

2. Gubin, M.M., Calaluce, R., Davis, J.W., Magee, J.D., Strouse, C.S., Shaw, D.P., Ma, L., Brown, A., Hoffman, T., Rold, T.L., \& Ulus Atasoy, U. Overexpression of the RNA binding protein HuR impairs tumor growth in triple negative breast cancer associated with deficient angiogenesis. Cell Cycle. 9, 3337-3346 (2010).

3. Keene, J.D., Komisarow, J.M., \& Friedersdorf. RIP-Chip: the isolation and identification of mRNAs, microRNAs and protein components of ribonucleoprotein complexes from cell extracts. Nature Protocols. 1 (1), 302-307 (2006).

4. Tenenbaum, S.A., Lager, P.J., Carson, C.C., \& Keene, J.D. Ribonomics: identifying mRNA subsets in mRNP complexes using antibodies to RNA-binding proteins and genomic arrays. Methods. 26 (2), 191-198 (2002).

5. Tenenbaum, S.A., Carson, C.C., Atasoy, U., \& Keene, J.D. Genome-wide regulatory analysis using en masse nuclear run-ons and ribonomic profiling with autoimmune sera. Gene. 317 (1-2), 79-87 (2003).

6. Tenenbaum, S.A., Carson, C.C., Lager, P.J., \& Keene, J.D. Identifying mRNA subsets in messenger ribonucleoprotein complexes by using cDNA arrays. Proc. Natl. Acad. Sci. U.S.A. 97 (26), 14085-14090 (2000).

7. Baroni, T.E., Chittur, S.V., George, A.D., \& Tennebaum, S.A. Advances in RIP-Chip Analysis. Methods in Molecular Biology. 419, 93-108 (2008).

8. Lopez de Silanes, I., Zhan, M., Lal, A., Yang, X., \& Gorospe, M. Identification of a target RNA motif for RNA-binding protein HuR. Proc. Natl. Acad. Sci. U.S.A. 101 (9), 2987-2992 (2004).

9. Lopez de Silanes, I., Lal, A., \& Gorospe, M. HuR: post-transcriptional paths to malignancy. RNA Biol. 2 (1), 11-13 (2005)

10. Grigull, J., Mnaimneh, S., Pootoolal, J., Robinson, M.D., \& Hughes, T.R. Genome-wide analysis of mRNA stability using transcription inhibitors and microarrays reveals posttranscriptional control of ribosome biogenesis factors. Mol. Cell Biol. 24 (12), $5534-5547$ (2004).

11. Hieronymus, H. \& Silver, P.A. Genome-wide analysis of RNA-protein interactions illustrates specificity of the mRNA export machinery. Nat. Genet. 33 (2), 155-161 (2003). 
12. Hieronymus, H., Yu, M.C., \& Silver, P.A. Genome-wide mRNA surveillance is coupled to mRNA export. Genes Dev. 18 (21), $2652-2662$ (2004).

13. Mukherjee, N., Corcoran, D.L., \& Nusbaum, J.D. Integrative Regulatory Mapping Indicates that the RNA-Binding Protein HuR Couples PremRNA Processing and mRNA Stability. Molecular Cell. 43, 1-13 (2011). 